\title{
ADCC potency assay: increased standardization with modified lymphocytes
}

\author{
Laurent Bretaudeau*, Véronique Bonnaudet \\ From 22nd European Society for Animal Cell Technology (ESACT) Meeting on Cell Based Technologies \\ Vienna, Austria. 15-18 May 2011
}

For few years now, the use of monoclonal antibodies represents a significant progress in different therapeutic applications. In addition to commercialization of new products, important efforts in research and development have been made to launch new therapeutic antibodies.

Many antibodies act through a mechanism of Antibody-dependant cell cytotoxicity (ADCC). National Health Agencies recommend or require the use of biological activity assays (potency) in order to characterize those pharmaceutical products. The ADCC assay combines the 3 following elements:

- The antibody of interest that is specific to a given antigen;

- The targeted cells that express the antigen of interest at their surface;

- The effector that can trigger the lysis the targeted cell when the antibody is linked to the antigen.
As the usually met ADCC assays use Natural Killer cells, isolated from healthy donors, as effectors they are hardly reproducible (Table 1 ). Thus, those assays can barely be validated when lots of pharmaceutical products are released. Furthermore, of the rare NK cell lines established in culture don't express the CD16 receptor needed for the ADCC function.

In this context, the use of standardized effectors should improve significantly the ADCC assays. Previous work has highlighted that human lymphocytes, modified to express the CD16 receptor, have acquired the ADCC functions [1]. Thanks to our specific know-how, clones of CD16+ lymphocytes have been produced on a large scale $\left(10^{9}\right.$ cellules). The results obtained have pointed out that cells stored in liquid nitrogen and used as soon as they were thawed, were usable for ADCC assays on a reproducible basis (Figure 1). Thanks to that approach,

Table 1 Advantages and drawbacks of ADCC effectors for the validation of a standardized ADCC assay

\begin{tabular}{|c|c|c|}
\hline ADCC effector types & Advantages & Drawbacks \\
\hline $\begin{array}{l}\text { Primary NK or PBMC, isolated from } \\
\text { donors }\end{array}$ & Representative from the genetic diversity & $\begin{array}{c}\text { Not convenient for standardization } \\
\text { Requirement for donor genotyping } \\
\text { Requirement to evaluate several donors for accurate comparison } \\
\text { Exposure of operators to biohazard } \\
\text { Significant ressources required (budget and time) for cell } \\
\text { preparation }\end{array}$ \\
\hline Modified NK cell lines & Increased suitability for standardization & $\begin{array}{c}\text { The NK activity may interfere with the measurement of the } \\
\text { ADCC-related lysis } \\
\text { Absence of functionally qualified batches of cells } \\
\text { Absence of biosafety qualified batches of cells } \\
\text { To be handled as a GMO }\end{array}$ \\
\hline CD16-transduced lymphocytes & $\begin{array}{c}\text { Increased suitability for standardization } \\
\text { Qualified batches available in a ready-to- } \\
\text { use format } \\
\text { Absence of NK activity-related background }\end{array}$ & To be handled as a GMO \\
\hline
\end{tabular}

\footnotetext{
* Correspondence: Ibretaudeau@clean-cells.com
}

Clean Cells, Boufféré, 85600, France 


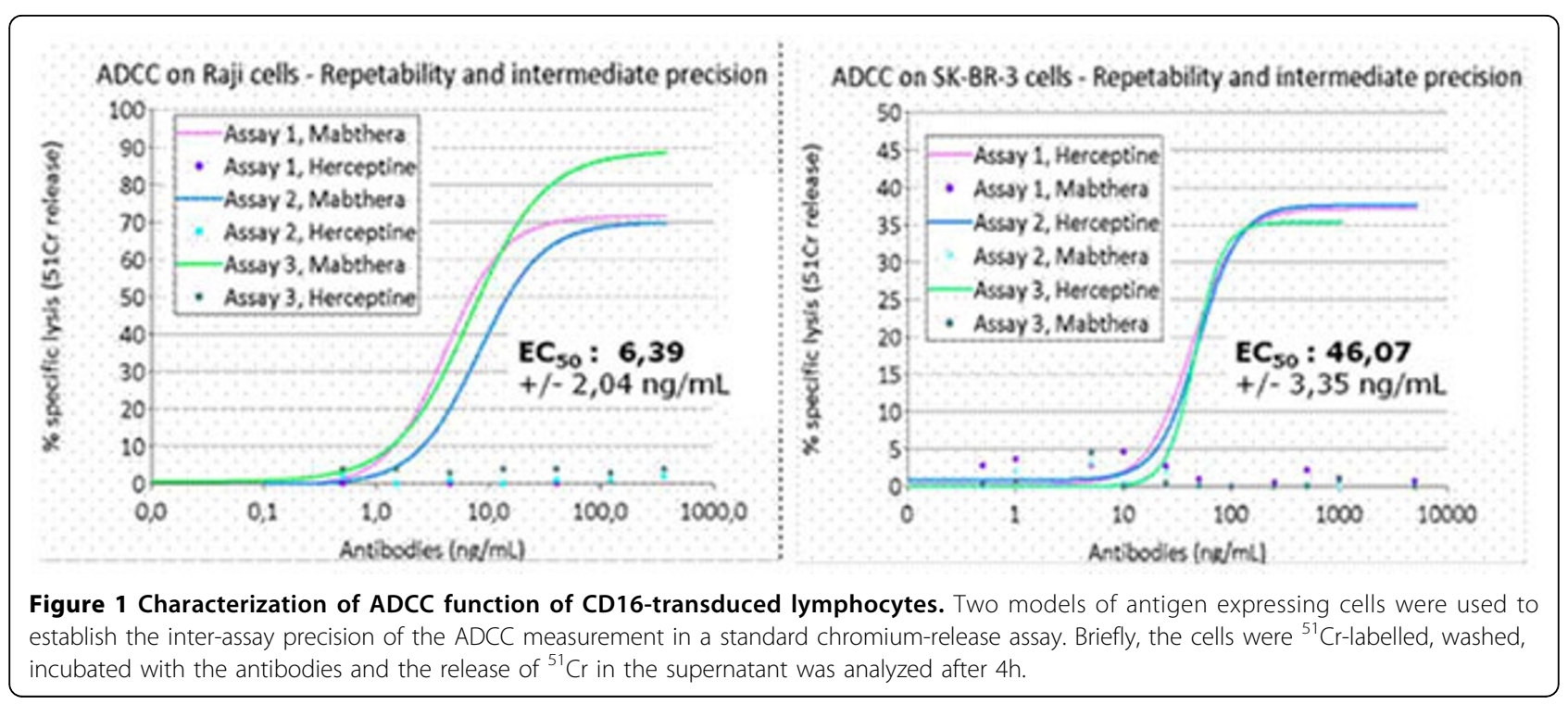

two models of ADCC measurement are characterized in the present presentation: CD20 and Her2neu.

The produced effector cells constitute a relevant alternative to replace the use of NK cells when the standardization of ADCC potency assay is needed.

Published: 22 November 2011

\section{Reference}

1. Clémenceau B, Congy-Jolivet N, Gallot G, Vivien R, Gaschet J, Thibault G, Vié H: Antibody-dependent cellular cytotoxicity (ADCC) is mediated by genetically modified antigen-specific human T lymphocytes. Blood 2006, 107(12):4669-77.

doi:10.1186/1753-6561-5-S8-P63

Cite this article as: Bretaudeau and Bonnaudet: ADCC potency assay: increased standardization with modified lymphocytes. BMC Proceedings 2011 5(Suppl 8):P63.

Submit your next manuscript to BioMed Central and take full advantage of:

- Convenient online submission

- Thorough peer review

- No space constraints or color figure charges

- Immediate publication on acceptance

- Inclusion in PubMed, CAS, Scopus and Google Scholar

- Research which is freely available for redistribution 